\title{
The influence of heat sink temperature on the seasonal efficiency of shallow geothermal heat pumps
}

\author{
Grzegorz Pełka ${ }^{1, *}$, Wojciech Luboń ${ }^{1}$, Anna Sowiżdżał ${ }^{1}$, and Daniel Malik ${ }^{1}$ \\ ${ }^{1}$ AGH-UST, Faculty of Geology, Geophysics and Environmental Protection, al. Mickiewicza 30, \\ 30-059 Cracow, Poland
}

\begin{abstract}
Geothermal heat pumps, also known as ground source heat pumps (GSHP), are the most efficient heating and cooling technology utilized nowadays. In the AGH-UST Educational and Research Laboratory of Renewable Energy Sources and Energy Saving in Miękinia, shallow geothermal heat is utilized for heating. In the article, the seasonal efficiency of two geothermal heat pump systems are described during the 2014/2015 heating season, defined as the period between 1st October 2014 and 30th April 2015. The first system has $10.9 \mathrm{~kW}$ heating capacity (according to European Standard EN 14511 B0W35) and extracts heat from three vertical geothermal loops at a depth of $80 \mathrm{~m}$ each. During the heating season, tests warmed up the buffer to $40^{\circ} \mathrm{C}$. The second system has a $17.03 \mathrm{~kW}$ heating capacity and extracts heat from three vertical geothermal loops at a depth of $100 \mathrm{~m}$ each, and the temperature of the buffer was $50^{\circ} \mathrm{C}$. During the entire heating season, the water temperatures of the buffers was constant. Seasonal performance factors were calculated, defined as the quotient of heat delivered by a heat pump to the system and the sum of electricity consumed by the compressor, source pump, sink pump and controller of heat pumps. The measurements and calculations give the following results: - The first system was supplied with $13857 \mathrm{kWh} / \mathrm{a}$ of heat and consumed $3388 \mathrm{kWh} / \mathrm{a}$ electricity. The SPF was 4.09 and the average temperature of outlet water from heat pump was $40.8^{\circ} \mathrm{C}$, and the average temperature of brine flows into the evaporator was $3.7^{\circ} \mathrm{C}$; - The second system was supplied with $12545 \mathrm{kWh} / \mathrm{a}$ of heat and consumed $3874 \mathrm{kWh} / \mathrm{a}$ electricity. The SPF was 3.24 and the average temperature of outlet water from heat pump was $51.6^{\circ} \mathrm{C}$, and the average temperature of brine flows into the evaporator was $5.3^{\circ} \mathrm{C}$. To summarize, the data shown above presents the real SPF of the two systems. It will be significant in helping to predict the SPF of objects which will be equipped with ground source heat pumps.
\end{abstract}

\section{Introduction}

In recent years in Poland the constant progress of the heat pump sector has been observed in contrast to many previous years. In 2015, it was expressed by an average $14 \%$ growth of

\footnotetext{
*Corresponding author: gpelka@geol.agh.edu.pl
} 
sales compared with 2014 . The most spectacular growth $(70 \%)$ was in air heat pumps in 2015 and this trend is expected to be continued [1,2].

The Educational and Research Laboratory of Renewable Energy Sources and Energy Saving in Miękinia is a unit of the Faculty of Geology, Geophysics and Environment Protection AGH-UST. At the Faculty, research connected with renewable energy sources has been conducted for many years [3-8]. In 2012, a research laboratory that would improve the quality of the research work was established.

The Laboratory is located in the former administrative building of the porphyry mine in Miękinia (35 km north-west of Kraków) The building has been completely redesigned, achieving energy-efficient building for the RES laboratory. Currently the building is heated by four heat pumps extracting heat from the ground. Heat from the ground is taken by vertical heat exchangers and a horizontal ground exchanger.

The heating system in Miękinia is measured by heat production, electricity consumption and energy taken from the heat source. Inlet and outlet temperatures for each of the heating circuits are metered. PoWoGaz flow meters are used with rotor transducers, PT100 resistance temperature probes and SchellCount energy counters. Everything is archived in the memory of the DigiEnergy monitoring system and it is possible to export data and process them. This system has also an implemented algorithm for heat calculation using flow rate and a temperature difference of the fluid being measured. The collected data were evaluated.

\section{Heat pumps parameters}

Heat pumps are heating devices which have high work efficiency. In order to specify the work of heat pumps, we use the following parameters:

- COP (Coefficient of Performance) - calculated according to PN-EN 14511 [9]. It is defined as a ratio of heating output divided by the electrical power input. It is measured in determined conditions of work. To calculate COP, the electrical power required from all components such as the compressor, controller, circulation pumps or fans of heat sources and sink are taken into account. For the circulation pump on the side of the heat sink, the electrical power demand needed to overcome the hydraulic resistance of the condenser is taken into account. This coefficient characterizes heat pump's work in the strictly defined conditions of temperature of heat source and heat sink.

- SCOP (Seasonal Coefficient of Performance) is calculated according to PN-EN-14825 [10]. This coefficient describes the annual average efficiency factor of heat pumps. SCOP shows how efficient a specific heat pump will be in a designated heating season and for designated heating demand profile. Seasonal Coefficient of Performance can be estimated at the design stage of building and this calculation can be used to predict future exploitation cost. SCOP is use to optimize a heating installation with heat pumps.

- SPF (Seasonal Performance Factor) is defined as ratio of heat production and electricity consumption during specified period. There are several types of SPF, which account for some additional elements of installation such as the pump of a central heating system, additional electric heaters, etc. $[11,12]$.

The most useful coefficient for ending user is Seasonal Performance Factor as it represents a real test of the efficiency of an installation. The bigger ratio responds to the lower costs of exploitation related with preparing heat by the user. On paper the SPF is defined as the ratio of heat generated by the heat pump and electricity consumption to work of all elements, such as compressor, controller, pumps of heat source and heat sink, electric heater installed on heat pump (this device was shut off during the time of test). Calculated SPF is equal to SPF 3 according to the methodology presented by Miara et. al [13]. 


\section{Heating system in the laboratory - description}

The heat pumps installed in the AGH-UST Educational and Research Laboratory of Renewable Energy Sources and Energy Saving in Miękinia work in three different heating systems. Two heat pumps prepare heat at a medium temperature $\left(35^{\circ} \mathrm{C}-40^{\circ} \mathrm{C}\right)$ and another two prepare heat with a higher temperature $\left(55^{\circ} \mathrm{C}\right)$. Low temperature's heat pumps reach $10.9 \mathrm{~kW}$ heating power with B0W35 conditions and COP is 4.4. The heat pumps producing high temperature heat have $17 \mathrm{~kW}$ power in B0W35 conditions and their COP is also 4.4. Each of the heat pumps has an independent heat source system. Three heat pumps have borehole heat exchangers and one of them has a horizontal ground source. The first one has three borehole heat exchangers (each of them at a depth $83 \mathrm{~m}$ ) and heat or chill is distributed on the building using the ventilation ducts (system A - Fig 1). The second heat pump has three borehole heat exchangers (each of them at a depth $87 \mathrm{~m}$ ) and heat or chill is distributed by underfloor heating (system B). The third heat pump has three borehole heat exchangers (each of them at a depth $100 \mathrm{~m}$ depth) as a source and the fourth has the closedloop located 1.5 meters underground $\left(600 \mathrm{~m}^{2}\right.$ of area). Two high temperature heat pumps share together one buffer tank and heat pumps produce high temperature heat for domestic hot water and to distribute heat to the building by means of radiators. The low temperature heat pumps work for independent buffer tanks (system C).

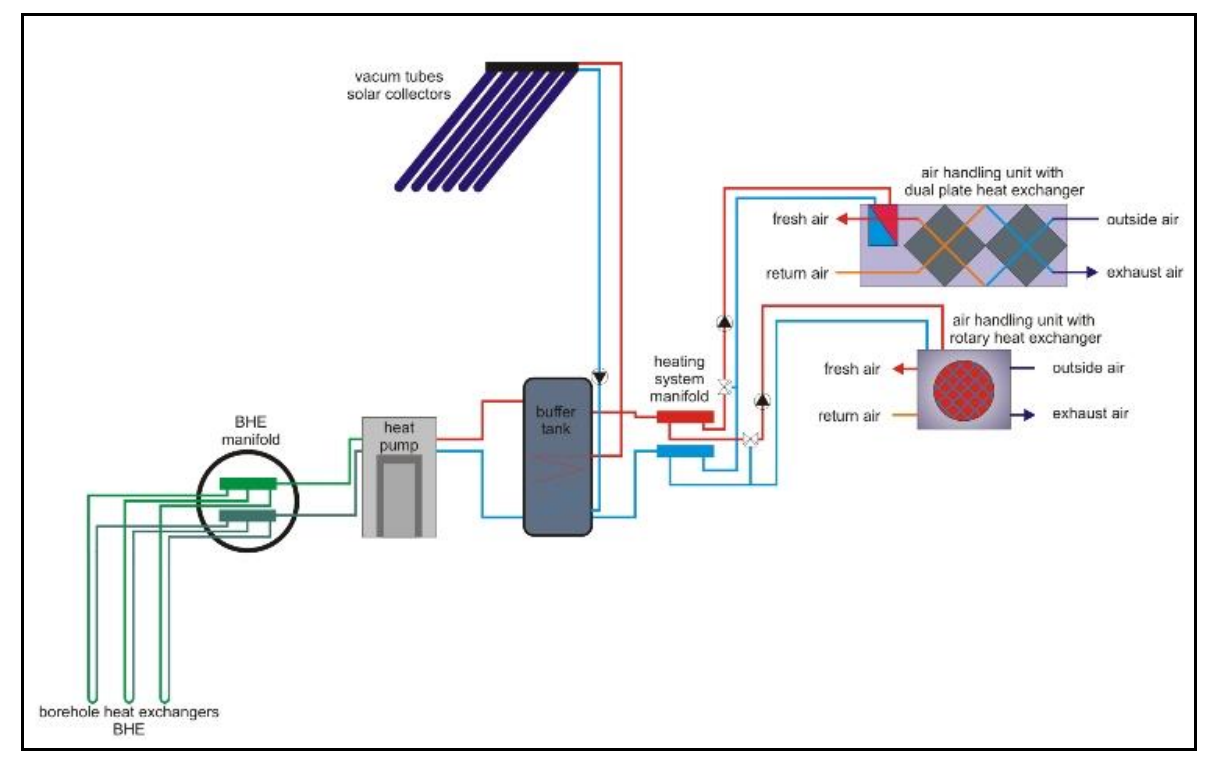

Fig. 1. A diagram of the system A in Laboratory in Miękinia. 


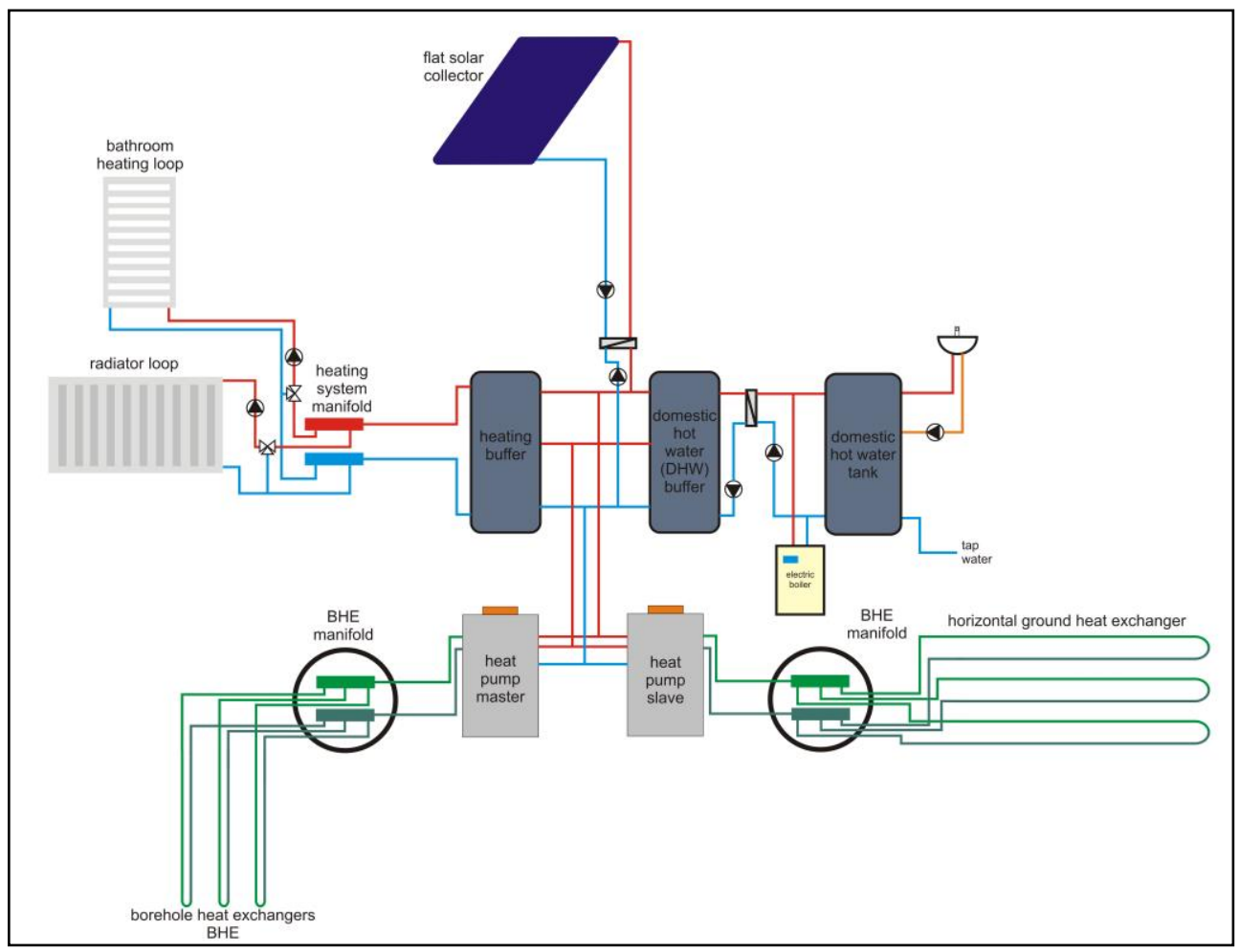

Fig. 2. A diagram of the system $\mathrm{C}$ in Laboratory in Miękinia.

\section{Heating system operation - results of research}

The heating system in the Laboratory in Miękinia is equipped with a control system and is able to archive data such as the heating power of each heating system, power demand of particular devices, supply and return temperature, temperature inside a buffer etc. Heating power is measured by impeller flow sensor and resistance temperature sensor and is calculated in DigiEnergy program. Electricity consumption is measured by one-phase and three phase meter. Data of the two heat pumps working during one heating season was analysed to determine the influence of heat sink temperature on the Seasonal Performance Factor. The heating season was defined as the time interval from $1^{\text {th }}$ October $201430^{\text {th }}$ April 2015.

Results of the research for system A show the real values of SPF which are attainable in heating systems with heat pumps producing low temperature heat. In this system, heat is used to supply the air handling units. During the test, temperature was set at constant value. The heat pump maintained a temperature of water in a buffer tank at $40^{\circ} \mathrm{C}$. In the case of system A, there existed a real possibility of increasing the SPF factor by connecting a set water temperature dependent on outdoor temperature and create the heating curve. System $\mathrm{C}$ in comparison to system A during the heating season provided relatively less heat. System A delivered $13857 \mathrm{kWh}$ of heat, consumed $3387 \mathrm{kWh}$ of electricity, while system $\mathrm{C}$ (with the vertical exchanger and a higher heating power device) supplied only $12545 \mathrm{kWh}$ of heat, consumed $3874 \mathrm{kWh}$ of electricity. The reason for this was less demand for heat generated in the system C. During the analysed period, radiators were closed most of the time and demand for hot domestic water wasn't high. The water 
temperature in system $\mathrm{C}$ was set at $50^{\circ} \mathrm{C}$, which corresponds to the convection radiator installation. The SPF of System A was 4.09, and the system C was 3.24. These results confirm that a floor-heating system is more appropriate for heat pumps than radiators [14]. The other energy parameters were presented in table 1.

Similar studies were conducted by Nouvel et. al. [15]. In this work the authors created a map of potential values of SPF for the operation parameters similar to the operation parameters in system $\mathrm{C}$. This paper shows that heat pumps with borehole heat exchangers as a heat source and heat sink temperature of $50^{\circ} \mathrm{C}$, located around Miekinia can be on the level 3.4. It is very similar to the results presented in this paper. The results of research published by the Coimbra University in Portugal [16] coincided with the results obtained by the heat pump in system A. A heat pump with seven borehole heat exchanger, each one with 125 meters of depth, heated water to $40^{\circ} \mathrm{C}$. Both the research in Portugal and that conducted by the Fraunhofer Institute for Solar Energy Systems ISE [13] show that heating systems with ground sources heat pumps achieve similar results.

The Seasonal Performance Factor of heat pumps at 4.09 and 3.24 receive during research in Laboratory in Miękinia may be used to conduct estimates for potential future users. The efficiency of heating systems with heat pumps depends on the heat sink. In the future, heating seasons need to be researched to increase the performance factors and it is intended that this study will be ongoing.

Table 1. Energy parameters of heating systems during 1th October 2014 to 30th April 2015 heating season.

\begin{tabular}{|c|c|c|}
\hline Parameter & System A & System C \\
\hline Average outside temperature $\left[{ }^{\circ} \mathrm{C}\right]$ & \multicolumn{2}{|c|}{5.3} \\
\hline Cooling power $[\mathrm{W} / \mathrm{m}]$ & 33.8 & 48.3 \\
\hline Average temperature of evaporator supply $\left[{ }^{\circ} \mathrm{C}\right]$ & 3.7 & 5.3 \\
\hline Average temperature of return from evaporator $\left[{ }^{\circ} \mathrm{C}\right]$ & 0.8 & 1.1 \\
\hline Average temperature of brine $\left[{ }^{\circ} \mathrm{C}\right]$ & 2.3 & 3.2 \\
\hline Average temperature of a sink supply $\left[{ }^{\circ} \mathrm{C}\right]$ & 40.8 & 51.6 \\
\hline Average temperature of return from a sink $\left[{ }^{\circ} \mathrm{C}\right]$ & 33.9 & 44.6 \\
\hline An average temperature of a sink $\left[{ }^{\circ} \mathrm{C}\right]$ & 37.3 & 48.1 \\
\hline Average of difference between sink and energy source $\left[{ }^{\circ} \mathrm{C}\right]$ & 35.1 & 44.9 \\
\hline The electricity demand $[\mathrm{kWh} / \mathrm{a}]$ & 3387.7 & 3874.0 \\
\hline The generated energy $[\mathrm{kWh} / \mathrm{a}]$ & 13857.1 & 12545.0 \\
\hline The energy from ground $[\mathrm{kWh} / \mathrm{a}]$ & 10399.1 & 11495.3 \\
\hline Seasonal Performance $\mathbf{F a c t o r}$ & $\mathbf{4 . 0 9}$ & $\mathbf{3 . 2 4}$ \\
\hline
\end{tabular}

\section{Summary and conclusions}

The AGH-UST Educational and Research Laboratory of Renewable Energy Sources and Energy Saving in Miękinia utilizes shallow geothermal heat by means of heat pumps. It is a good example of a practical use of heat pumps.

The Seasonal Performance Factor of heat pumps receive during research in Laboratory in Miękinia may be used to perform estimates for potential future users. The efficiency of heating systems with heat pumps is depending on the heat source. Research of heat pumps operation to increase the performance factors will be undergoing in the future. 


\section{Acknowledgments}

The paper was prepared under AGH-UST statutory research grant no. 11.11.140.321 and grant no. 11.11.140.704.

\section{References}

1. B. Kepinska, Geothermal Energy Use - Country Update for Poland, 2013-2015 (EGC Proceeding, Strasbourg, France, 2016)

2. W. Górecki, E. Hałaj, J. Kotyza, A. Sowiżdżał, W. Luboń, G. Pełka, D.Woś, M. Kaczmarczyk, M. Hajto, M. Kaczmarczyk, P.Lachman, Effective use of renewable energy sources (2015)

3. W. Górecki, A. Sowiżdżał, M. Hajto, A. Wachowicz-Pyzik, Environ. Earth Sci. 74, 7487-7495 (2015)

4. A. Sowiżdżał, W. Luboń, G. Pełka, Prospective areas for geothermal energy resources utilization In the Polish Lowlands (Conf. mat. from the IGD, Slovakia, 2009)

5. A. Sowiżdżał, B. Papiernik, G. Machowski, M. Hajto, Geol. Quart. 57, 729-744 (2013)

6. A. Sowiżdżał, Carpath. J. Earth Env. 10, 237-246 (2015)

7. A. Sowiżdżał, Appl. Ecol.Environ. Res. 14, 2, 555-574 (2016)

8. A. Sowiżdżał, M. Kaczmarczyk, Geol. J. 51, 65-76 (2016)

9. PN-EN 14511-3:2013-12, Air conditioners, liquid chilling packages and heat pumps with electrically driven compressors for space heat ing and cooling - Part 3: Test methods

10. PN-EN 14825:2016-08, Air conditioners, liquid chilling packages and heat pumps, with electrically driven compressors, for space heating and cooling. Testing and rating at part load conditions and calculation of seasonal performance

11. P. Lachman, InstalReporter 3, 42-47 (2013)

12. R. Nordman, A Zottl, SEPEMO-Build - a European project on seasonal performance factor and monitoring for heat pump systems in the building sector (2011)

13. M. Miara, D. Gunther, T. Kramer, T. Oltersdorf, J. Wapler, Heat pump efficiency. Analysis and Evaluation of Heat Pump Efficieny in real-life conditions (2011)

14. I. Sarbu, C. Sebarchievici, Energies 9, 4, 228 (2016)

15. R. Nouvel, M. Cotrado, D. Pietruschka, European Mapping of Seasonal Performances of Air-Source and Geothermal Heat Pumps for Residential Application, CISBAT (2015)

16. A.D. Carvalho, High Efficiency Ground Source Heat Pump Systems for Sustainable Building Space Conditioning, $\mathrm{PhD}$ Thesis (2015) 